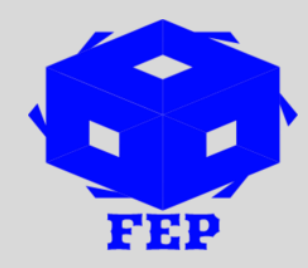

\title{
STUDY OF CONNECTION BETWEEN STOCK MARKET AND ECONOMIC PERFORMANCE IN MALAYSIAN CONTEXT
}

Ngee Derk ${ }^{1}$

${ }^{1}$ Universiti Utara Malaysia, Sintok, Malaysia

*Corresponding Author: Ngee Derk Article Received: 04-11-19
Accepted: $30-01-20$

Published: 05-02-20

Licensing Details: Author retains the right of this article. The article is distributed under the terms of the Creative Commons Attribution-Non Commercial 4.0 License (http://www.creativecommons.org/licences/by-nc/4.0/) which permits non-commercial use, reproduction and distribution of the work without further permission provided the original work is attributed as specified on the Journal open access page.

\begin{abstract}
The focus of the study is to test the stock market performance influence on the economic growth for time series for the period of 2002 to 2018 on quarterly basis. In this study, the performance measures included standard deviation which is measure of volatility, total value traded shared as measure of liquidity, turnover ratio as measure of liquidity, and stock market capitalization ratio as a measure of the size. The focus of the study is the Malaysian stock exchange market. The study utilized real GDP as an indicator of economic growth. The exchange rate and the interest rates are used as control variables. The study used Vector Autoregressive model and the Granger causality test are utilized for finding the directional relationship between the stock market and economic growth connection. Results states that variables are statistically insignificant and there is no meaningful relationship found.
\end{abstract}

Keywords: Stock Market, Economic Growth, Vector Autoregressive, Granger causality

\section{INTRODUCTION}

For any country's economic growth, stock market plays important function. Buying and selling of the stock is the main stock market function. Therefore, stock markets help in raising capital and channelizing the public savings. It also functions to form capital by encouraging savers to convert their wealth into profitable investment. Risk management and 
diversification is another function performed by stock markets. It also reduces risk through the diversification of investor portfolio which will maximize their return.

The influence of stock market on GDP is that it effects consumer confidence and the financial conditions. The stock market under the conditions of bull market trend, creates optimism; whereas, under the conditions of bear trend, there is negative influence on GDP as companies cut cost and workers (Koller, 2010).

There are some studies which indicate that economic growth influence the stock markets development as the financial development lead to follow economic growth. For example, Christopher (2011) states that stock market plays important contribution in economic growth of a country.

\section{Research Problem}

In any country, the focus of developing stock market is to assist companies in fund raising for higher level of expansion and productive investment. It helps channelizing savings. As the Malaysia is a developing country, it needed to stimulate economic growth. The problem this study is investigating is that there is shortage of evidence for the influence of stock market on driver of economic development. The study tests the relationship between stock market and the economic growth of country. So the main research question is 'What are the effects of stock market performance on the economic growth of Malaysia?

\section{Research objective}

The key research objective is to understand the relationship between stock market performance and economic growth in the Malaysian context.

\section{LITERATURE REVIEW}

There are four hypotheses which states the relationship between stock market progress and economic growth (Mittal, 2017; Enisan \& Olufisayo, 2007; Christopher, 2011; Tumaini, 2015). Efficient market hypothesis is the first hypothesis which states that stock market in a stock exchange are based on full information available. Therefore, efficient market hypothesis states that an efficient market will help savers to allocate their funds in efficient productive resources which will be increasing the resources and economic development (Jackline, 2017).

Supply leading hypothesis is the second hypothesis which states that financial development in a country causes economic growth. The hypothesis is also known as 'finance-led growth hypothesis'. Based on this perspective, the effects run from financial development to economic growth. The effects are caused by bringing improvement in efficiency of capital 
accumulation or an increase in the rate of savings as well as the rate of investment. If there is well functioning system in place, it can help in mobilization of resources and lead to economic growth (Karim, 2017).

Demand-following hypothesis is the third main hypothesis which states that financial development happens after the economic growth occurs. Christopher (2011) suggest that stock market bring improvement in economic growth of a country as it creates demands for financials services resulting in development of financial institutions and markets. Patrick (1966) suggests that financial development and economic growth depends on the stage of economic development. Supply lending view can stimulates real capital formulation during early stage of economic development. As the new financial services are created, it bring with it some opportunities for investors and savers and causes enhancement of economic growth.

The last and fourth hypothesis can be divided in to two parts. The first part is 'Feedback hypothesis' refers to combination between supply-leading and demand-following hypotheses. The hypothesis highlight a bi-directional relationship between economic growth and stock market. The neutral hypothesis is the second part of the hypothesis which states that there is no relationship between financial development and economic growth. A country having welldeveloped stock markets promoting higher level of economic expansion through technological changes and product and services innovation. The result is that there is higher demand created for stock market products. In such situation, stock market responds to the changes causing stimulation to economic growth. Thus, the hypothesis concludes that financial and economic development are positively interdependent and their relationship could lead to bi-directional causality (Zivengwa \& Bokosi, 2011).

A study by Mweembe Mundena, Robert Pickson, and Wonder Agbenyo (2019) tested the stock market development and economic growth interrelationship in Zambian context. The study is based on Granger causality test and VAR model and used quarterly time series data 1996Q1 to 2105Q4. The results are that there is a unidirectional causality running from market capitalization to economic growth.

A study examined the dynamic relationship between stock market development and economic growth in Zambia. Using VAR model and Granger causality test on quarterly time series data 1996Q1-2015Q4. The results showed a unidirectional causality running from market capitalisation to economic growth. Besides, it found that fluctuations in economic growth have significant predictive impacts on the current market capitalization.

A study by Ali Raza Sattar, Muhammad Aamir Ali, Mohsin Rehman, and Sehrish Naeem (2018) tested the influence of stock market on economic growth in three countries including 
China, India, and Pakistan. The data in this study is based on 25 years from the period of 1993 to 2016. Panel regression and Hausman specific test and random effect model are utilized in the study. Results shows that GDP is positively predicted by stock market capitalization.

A study by Chepkoech (2017) tested the influence of relationship between stock market capitalization and economic growth in Kenya for the period of 2005 to 2015 on quarterly basis. The investigation was made based on regression analysis. Results shows that stock market capitalization has positive influence on economic growth positively.

A study by Onwukeme, Ogochukwu, and Raifu (2017) tested the relationship between stock market development and economic growth in African countries. The countries included in the study were Zimbabwe, Zambia, Tunisia, Swaziland, South Africa, Nigeria, Morocco, Mauritius, Kenya, Ghana, Egypt, Cote d'Ivoire, and Botswana. The time period of the study was from 1990 to 2014. The method of analysis was based on dynamic ordinary least square, fully modified ordinary least square, random effect, and fixed effect. The results show that stock market development is positively associated with economic growth in Africa.

A study by Kumar and Padhi (2015) investigated the impact of stock market development on the economic growth for period of 1995 to 2012 for 27 emerging economies utilizing the annual panel data. For testing the stationary properties, the second generation panel unit root test is used. For testing the causality among the variables, heterogeneous panel causality test is applied. The findings show that stock market development is positively and significantly associated with economic growth.

A study by Kamal (2013) tested the effects of financial development and economic growth for the period of 1988 to 2012 for annual data in Egypt. Variables in the study were market capitalization for market size and total value of stock traded as a percentage of GDP to measure market liquidity. The results showed that in this particular market, there is no significant effects of stock market development on economic growth of the country.

A study by Dombou (2016) tested the stock market return volatility and economic growth. GARCH framework is used for apprehending return volatility and VAR framework for capturing connection between stock market and economic growth. The study used the quarterly data for the period of 2000 to 2015 for the Ivory Coast, Nigeria, and Cameroon. The results however were insignificant relationship between the stock market development and the economic growth of a country.

Masoud tested the relationship between stock market performance and economic growth. The data of the study was for developing countries as well as included the emerging market and 
for the period of 1996 to 2001 . Results showed that market capitalization ratio is found to be producing positive significant correlation with the country's GDP.

\section{METHODOLOGY}

The study utilized quarterly time series data for the period of 2002 to 2018 for investigation of the relationship between stock market performance and the economic growth. The endogenous growth theory states that long term growth is based on endogenous variables. Some proxy variables are utilized for determining the stock market performance which are stock market volatility, stock market liquidity, and stock market capitalization; while, real GDP is used as a measure of economic growth in the study. Inflation, interest rate, and exchange rate are used as control variable in the study.

For measuring the size of stock market relative to the economy, stock market capitalization ratio is utilized. Based on the efficient market hypothesis, the market size contributing growth through capital mobilization and risk diversification in an economy (Tumaini, 2015).

For measuring the efficiency of the market, stock market liquidity is utilized. The total value of shares traded ratio and turnover ratio is used for measuring the liquidity. Based on ceteris paribus assumption of holding other things constant, stock market liquidity is treated as independent variable and the real GDP is used as dependent variable. Economic growth is enhanced using the stock market liquidity since it allow investors the accessibility to their wealth prior the completion of the project through selling their stake.

Stock market volatility indicate the dispersion of returns for a given security. Based on capital asset pricing model, in situation where volatility increases, risk will increase accordingly thus risk premium will be increasing as investors tend to be compensated for the higher risk. It will also increase the cost of borrowing which will create burden for the firms to afford. In such situation, firms will be postponing their expansion and productivity which will hamper the economic growth of a country.

Finally, real growth domestic product is utilized for measurement of the economic growth rate. Furthermore, we used quarterly published discount rate and quarterly published exchange rate against US dollars are used as control variables.

\section{FINDINGS}

\section{Descriptive Analysis for the Research Variables}

Descriptive analysis for the research variables are provided below. 
Table 1

Descriptive Analysis for the Research Variables

\begin{tabular}{lllll}
\hline \multicolumn{1}{c}{ Research Variables } & Mean & Median & Maxim & Minim. \\
\hline Interest Rate & 0.104444 & 0.074500 & 0.171500 & 0.075000 \\
Exchange Rate & 0.047477 & 0.040750 & 0.174700 & 0.045000 \\
Market Capitalization to GDP & 0.747444 & 0.414114 & 1.447441 & 0.047144 \\
Market Volatility & 4.407757 & 5.055444 & 11.41104 & 0.054144 \\
Total Value Traded Share & 0.144474 & 0.145041 & 1.077757 & 0.047750 \\
Turnover Ratio & 0.141447 & 0.114174 & 0.540441 & 0.074147 \\
Real GDP Growth Rate & 1.110447 & 0.047100 & 14.01150 & -7.577 \\
\hline
\end{tabular}

The above table present the descriptive statistics. For the interest rate, the average rate is 0.10 with median of 0.097 , minimum value of 0.085 and maximum value of 0.192 . for the exchange rate, the mean value is 0.078 with minimum value of 0.04 and maximum value of 0.18. for market capitalization to GDP, the mean value is 0.939 with minimum value of 0.039 and maximum value of 2.678. For market volatility, the mean value is 6.30 with minimum value of 0.056 with maximum value of 22.62 . For total value traded share, the minimum value is 0.039 with maximum value of 1.099 and mean value is 0.237 . For turnover ratio, the mean value is 0.241 with minimum value of 0.097 with maximum value of 0.570 . Finally, real GDP growth rate, the mean value is 1.11 with minimum value of -8.589 with maximum value of 14.022 .

\section{Normality test for the Research Variables}

Table 2

Normality Test for the Research Variables

\begin{tabular}{lllll}
\hline Research Variables & Skewness & Kurtosis & Jarque-Bera & P value \\
\hline Interest Rate & 1.608144 & 4.581485 & 44.48654 & 0.000 \\
Exchange Rate & 1.658088 & 4.048405 & 45.84684 & 0.000 \\
Market capitalization to GDP & 1.045806 & 5.680841 & 15.51866 & 0.0055 \\
Market Volatility & 1.015540 & 5.445181 & 15.10401 & 0.0055 \\
Total Value Traded Share & 1.848104 & 6.611464 & 85.56806 & 0.000 \\
Turnover Ratio & 1.185805 & 4.815680 & 54.16488 & 0.000 \\
Real GDP Growth Rate & 0.458454 & 5.648606 & 5.168646 & 0.505 \\
\hline
\end{tabular}

Above table shows the normality related statistics for the variables. The results shows that some variables are no variable is normally distributed with the exception of real GDP growth rate since all the variables probability are lower than 0.05 with the exception of real GDP growth rate for which the value is higher than 0.05 .

\section{Unit Root Test - Stationarity Assumption}

For establishing the stability of the variables, stationarity test is utilized. The stationarity test for all the variables for the period of 2002 to 2018 is provided by utilizing the Augmented Dickey Fuller test. The figure provided below gives the stationarity of the variables and it can be observed that some variables are not stationary while others achieve stationarity level. The results are similar to the one presented for Augmented Dickey Fuller unit root test. 


\section{Co-integration using Johansen Model}

Co-Integration is applied between the research variables in Egypt from 2002 to 2018 using Johansen co-integration test to test whether there is a correlation relationship between the variables. Johansen test is used rather than Engle granger co-integration test because Johansen test permits more than one Co-integration relationship, than the Engle granger test.

Table 3

\begin{tabular}{|c|c|c|c|c|}
\hline \multirow{2}{*}{\multicolumn{2}{|c|}{$\begin{array}{l}\text { Hypothesized } \\
\text { No. of CE(s) Eigenvalue }\end{array}$}} & \multirow{2}{*}{$\begin{array}{c}\text { Trace } \\
\text { Statistic }\end{array}$} & 0.05 & \\
\hline & & & Critical Valu & Prob.** \\
\hline None * & 0.955777 & 575.5795 & 555.7554 & 0.0000 \\
\hline At most $3 *$ & 0.489480 & 98.75955 & 95.75577 & 0.0555 \\
\hline At most 3 & 0.555594 & 57.57575 & 79.85889 & 0.5775 \\
\hline At most 3 & 0.544557 & 50.75558 & 47.85755 & 0.7855 \\
\hline At most 4 & 0.555557 & 55.05775 & 59.79707 & 0.8890 \\
\hline At most 5 & 0.077708 & 4.850855 & 55.49475 & 0.8545 \\
\hline At most 7 & 0.008055 & 0.508577 & 5.845477 & 0.4759 \\
\hline
\end{tabular}

The above table provide details about Johansen co-integration test for the variables. The test statistics indicate that there is no co-integration between the variables which implies that Vector Autoregressive Model can be recommended for testing the relationship.

\section{VAR and Granger Causality for Testing the Research Hypotheses}

Before run the VAR model, the lag length criterion must be noted, so each variable will be tested to figure out what is the optimal lag for each, in order to do so AIC (Akaike information criterion) will be noted in the tests as it is the most popular and common one. Results show that Real GDP has 8 lags, Interest Rate has 2 lags, Exchange Rate has 1 lag, Market Capitalization to GDP Ratio has 2 lags, Standard Deviation has no lags, Total Value Traded Shares to GDP Ratio has 1 lag and Turnover Ratio has 1 lag.

\section{Vector Autoregressive (VAR) Model}

Based on the previous studies, the Vector Autoregressive model is tested. The co-integration states that there is no co-integration between the study variables which implies that suitable regression model is the VAR model.

The VAR model points out the insignificant nature of market capitalization and real GDP because of insignificant $\mathrm{p}$ value and the corresponding t-value. Hence, we reject the hypothesis that stock market capitalization influence the economic growth positively and significantly.

For stock market liquidity, VAR model indicate that the relationship between total value traded shares and real GDP is statistically insignificant because of lower t-statistics and 
corresponding insignificant $\mathrm{p}$ value. Based on these results, we also reject the hypothesis that stock market liquidity influences the economic growth positively and significantly.

For testing the stock market volatility, VAR model results indicate that the relationship between standard deviation and real GDP is statistically insignificant. Based on these results, stock market volatility influences the economic growth negatively. For control variables, the relationship between exchange rate, discount rate, stock market and the economic growth is statistically insignificant.

Finally, the VAR model indicate that the stock market is not influencing the economic growth in Malaysia for the selected study period. The results are not matching with literature such as study by Mwambwene (2013); Kumar and Podhi (2015); and Tuony (2012).

\section{Granger Causality Test}

After testing the suitable regression model, we tested the causality using the Granger causality test. The test is based on lag length of 8 lags. The results of the Granger Causality test indicate that stock market variables including the total value traded shares and turnover ratio along with stock market capitalization, the stock market volatility based on standard deviation, and the control variables including exchange rate and the discount rate does not indicate causing economic growth since their $\mathrm{p}$ value are greater than the critical value of 0.05. hence, we reject the $\mathrm{H} 4$ that the unidirectional causality for stock market performance and economic growth.

\section{CONCLUSION AND RECOMMENDATION}

The objective of the study was to test the stock market performance on the economic growth using the real GDP for the Malaysian economy for the period of 2002 to 2018 on quarterly basis. The results indicate that there is insignificant relationship between stock market capitalization and the economic growth as measured by real GDP. Furthermore, we also found insignificant relationship between stock market liquidity including total value traded shares and the turnover ratio and their relationship with the economic growth. The relationship between stock market volatility and economic growth is found to be insignificant. We also used the Granger causality test for finding the directional causality test between the variables. Results indicate that there is insignificant relationship between stock market performances and economic growth. Our results are similar to the findings of the some of the studies including Badr (2015); Kamal (2013); and Karim (2017). 


\section{References}

Bilgehan, T., \& Erol, Y. (2019). The causality between economic growth and stock market in developing and developed countries Toda-Yamamoto approach. Theoretical and Applied Economics, Volume 32(2), 79-90.

Cameroon, Ivory Coast and Nigeria.

https//www.researchgate.net/publication/320546474

Christopher, Q. (2011). Stock market capitalization and economic growth in Ghana (Thesis for award of master of philosophy degree in economics submitted to the department of economics, University of Cape Coast)

Dany, D. (2017). Stock markets, volatility and economic growth evidence from

Frederic, S. (2016). Financial Markets and institutions ( $7^{\text {th }}$ ed.).

Jackline, C. (2017). Relationship between market capitalization and economic growth in Kenya; a research project submitted to school of business, university of Nairobi.

Mona, K. (2013). Financial development and economic growth in Egypt; a reinvestigation, Munich Personal RePEc Archive.

Mweembe, M., Robert, P., \& Wonder, A. (2019). The Dynamics of the Relationship between Stock Market Development and Economic Growth in Zambia, European Online Journal of Natural and Social Sciences, 8(2), 239-252.

Najeb, M.H. (2013). The impact of stock market performance upon economic growth, International Journal of Economics and Financial Issues, 3(4),788-798.

Onwukeme, O., \& Isiaka, R. (2017). Stock Market Development and Economic Growth Evidence from Africa, Euro-Asian Journal of Economics and Finance,5(1), 23-44.

Osma, B.M. (2015). Stock market development and economic growth Evidences from Egypt, International Journal of Trade, Economics and Finance, 6(2).

Pramod, K., Puja, P. (2015). On the linkage between stock market development and economic growth in emerging market economies Dynamic panel evidence. Review of Accounting and Finance, 14(4), $363-381$.

Raza, S.A., Aamir, S., Mohsin, R., Sehrish, N. (2018). The impact of stock market development on economic growth; panel study in the economies of Pakistan, India and China, Austin Journal of Business Administration and Management, 2(1)

Saba, K. (2017). Effect of stock market development on economic growth of major South Asian and East Asian economies A Comparative Analysis. Journal of business studies quarterly. 8(3).

Tan, Z., Koomson, P., Ding, G., Chibsah, R., \& Obu, L. (2018). Stock market and economic growth Evidence from Granger causality test. Journal of Economics and International Business Management, 6(2), 20-29,

Tichaona, Z., Joseph, M., Fanwell, B.K., Tendai, K. (2011). Stock market development and economic growth in Zimbabwe, International Journal of Economics and Finance, $3(5)$.

Tim, K. (2010). Measuring and Managing the value of companies(Fifth edition).

Tumaini, B. (2015). Stock market development and economic growth in Uganda a time series analysis for the period (1998Q1-2012Q4), International institution of social studies 